\title{
INFLUENCE OF THE SUBSTRATE TEMPERATURE ON THE STRUCTURAL, OPTICAL AND THERMOELECTRIC PROPERTIES OF SPRAYED $\mathrm{V}_{2} \mathrm{O}_{5}$ THIN FILMS
}

\author{
VPLIV TEMPERATURE PODLAGE NA STRUKTURNE, OPTIČNE \\ IN TERMOELEKTRIČNE LASTNOSTI NAPRŠENE TANKE PLASTI \\ $\mathrm{V}_{2} \mathrm{O}_{5}$
}

\author{
Yelsani Vijayakumar ${ }^{1}$, Katta Narasimha Reddy ${ }^{1}$, Annasaheb Vitthal Moholkar ${ }^{2}$, \\ Musugu Venkata Ramana Reddy ${ }^{1}$
}

${ }^{1}$ Thin Films and Nanomaterials Research Laboratory, Department of Physics, Osmania University, 500007 Hyderabad, India 2Thin Film Nanomaterials Laboratory, Department of Physics, Shivaji University, Kolhapur, India vijay.yelsani@gmail.com

Prejem rokopisa - received: 2014-05-13; sprejem za objavo - accepted for publication: 2014-07-11

\begin{abstract}
Vanadium pentoxide $\left(\mathrm{V}_{2} \mathrm{O}_{5}\right)$ thin films were deposited using the spray pyrolysis technique. An aqueous solution of ammonium vanadate with a $0.05 \mathrm{M}$ concentration was used for depositing $\mathrm{V}_{2} \mathrm{O}_{5}$ thin films at three different substrate temperatures on glass substrates. The structural and optical characteristics of the $\mathrm{V}_{2} \mathrm{O}_{5}$ thin films were examined with X-ray diffraction (XRD) and double-beam UV-visible spectrophotometry. The X-ray diffraction study of the $\mathrm{V}_{2} \mathrm{O}_{5}$ thin films revealed a polycrystalline nature of the orthorhombic structure with the preferred orientation of $(001)$. The crystallite size $(d)$ was calculated from the $(001)$ diffraction peak using the Debye-Scherrer formula. From the optical absorbance measurements, the optical band gap $\left(E_{\mathrm{g}}\right)$ was determined. A scanning electron microscope (SEM) was used to characterize the morphology of the films. Electrical measurements of the films indicated that the resistance decreases with an increase in the substrate temperature. From the thermoelectric measurements, the Seebeck coefficient was determined.
\end{abstract}

Keywords: $\mathrm{V}_{2} \mathrm{O}_{5}$ thin film, spray pyrolysis, optical band gap, activation energy, temperature coefficient of resistance, Seebeck coefficient

Tanka plast vanadijevega pentoksida $\left(\mathrm{V}_{2} \mathrm{O}_{5}\right)$ je bila nanesena s tehniko piroliznega brizganja. Za nanos tanke plasti $\mathrm{V}_{2} \mathrm{O}_{5}$ na podlago iz stekla pri treh različnih temperaturah podlage je bila uporabljena koncentracija vodne raztopine amonijevega vanadata $0,05 \mathrm{M}$. Značilnosti strukture in optične značilnosti tanke plastiV $\mathrm{O}_{5}$ so bile preiskovane z rentgensko difrakcijo in z dvožarkovno UV-vidno spektrofotometrijo. Rentgenska difrakcija tanke plasti $\mathrm{V}_{2} \mathrm{O}_{5}$ je odkrila polikristalno naravo ortorombične strukture s prednostno orientacijo (001). Velikost kristalitov $(d)$ je bila izračunana iz difrakcijskega vrha $(001)$ z Debye-Scherrerjevo formulo. Iz meritev optične absorbance je bila določena pasovna vrzel $\left(E_{\mathrm{g}}\right)$. Za karakterizacijo morfologije plasti je bil uporabljen vrstični elektronski mikroskop (SEM). Električne meritve tankih plasti so pokazale, da se upornost zmanjšuje $\mathrm{z}$ naraščanjem temperature podlage. Iz termoelektričnih meritev je bil določen Seebeckov koeficient.

Ključne besede: tanka plast $\mathrm{V}_{2} \mathrm{O}_{5}$, pirolizno brizganje, optična pasovna vrzel, aktivacijska energija, temperaturni koeficient upornosti, Seebeckov koeficient

\section{INTRODUCTION}

Vanadium oxide is of enormous research interest because of its multivalent nature. The $\mathrm{VO}_{2}, \mathrm{~V}_{2} \mathrm{O}_{3}$ and $\mathrm{V}_{2} \mathrm{O}_{5}$ multivalent oxides exhibit a lot of fascinating and novel properties. Among these vanadium pentoxide $\left(\mathrm{V}_{2} \mathrm{O}_{5}\right)$ has been extensively studied and because of its highest oxidation state in the $\mathrm{V}-\mathrm{O}$ system, a wide band gap, a better stability and its electrothermal effects it is useful for device applications. $\mathrm{V}_{2} \mathrm{O}_{5}$ is used in various devices, such as color filters, smart windows ${ }^{1}$ and infrared detectors, ${ }^{2}$ as well as gas sensing ${ }^{3}$ and catalysis. ${ }^{4}$

Vanadium pentoxide thin films are prepared with different physical and chemical techniques, namely, thermal evaporation, ${ }^{5}$ pulsed-laser deposition, ${ }^{6}$ sputtering, ${ }^{7}$ inorganic sol-gel method ${ }^{8}$ and spray pyrolysis. ${ }^{9}$ Being simple and less expensive, the spray-pyrolysis technique (SPT) is a better chemical technique, carried out at a lower cost, for the preparation of thin films with a larger area. In addition, it provides an easy way to dope any element in the ratio of a required proportion through the solution medium. This method is convenient for preparing pinhole-free, uniform thin films with the required thickness. ${ }^{10}$ In the spray-pyrolysis technique, various deposition parameters like the compressed-air pressure, the spray rate, the substrate temperature, the distance between the nozzles and the substrate and the cooling rate after deposition also affect the physical, electrical and optical properties of thin films. ${ }^{11}$ However, few efforts have been made to systematically investigate the effects of deposition parameters on the structural, electrical and optical properties of the vanadium oxide thin films deposited with SPT. ${ }^{12}$

In the present investigation, a synthesis of $\mathrm{V}_{2} \mathrm{O}_{5}$ made with the spray-pyrolysis technique was investigated at 
low substrate temperatures, and the structural, optical and thermoelectric properties of the films are reported.

\section{MATERIAL AND METHODS}

Before depositing the $\mathrm{V}_{2} \mathrm{O}_{5}$ thin films, the glass substrates were cut into $2.25 \mathrm{~cm} \times 2.25 \mathrm{~cm}$ pieces and subjected to cleaning and degreasing protocols. $0.05 \mathrm{M}$ concentrated ammonium vanadate with deionized water was used as the starting material. The spray solution was introduced into the air stream by means of a syringe pump. In the spray system, compressed and purified air was used as the carrier gas with a $3 \mathrm{~kg} / \mathrm{cm}^{2}$ pressure and the solution spray rate was maintained at $3 \mathrm{~mL} / \mathrm{min}$. The distance between the spray nozzle and the substrate was fixed at $25 \mathrm{~cm}$. The spray head moved in the horizontal plane due to a stepper motor to achieve a uniform deposition of the films on the heated substrates maintained at different temperatures, i.e., $(250,300$ and 350$){ }^{\circ} \mathrm{C}$. The substrate temperature was controlled through a digital temperature controller with an accuracy of $\pm 5^{\circ} \mathrm{C}$.

The crystal structures of the films were studied with XRD using a Philips Xpert diffractometer with $\mathrm{Cu}-\mathrm{K} \alpha$ radiation (the X-ray wavelength $\lambda=0.154 \mathrm{~nm}$ ). Microphotography of the films was carried out using a scanning electron microscope. Optical parameters were calculated from the absorption spectra recorded against the wavelength using a Lab India UV-Visible 3000 spectrophotometer. The resistance of the films was measured with the two-point probe method using a Keithley electrometer (model no. 196) in the temperature range of $27-100{ }^{\circ} \mathrm{C}$. The metallic contacts on the films were made of silver paint. Thermoelectric power [TEP] was measured using a home-built system with two copper blocks, one for the heat source and the other one for the

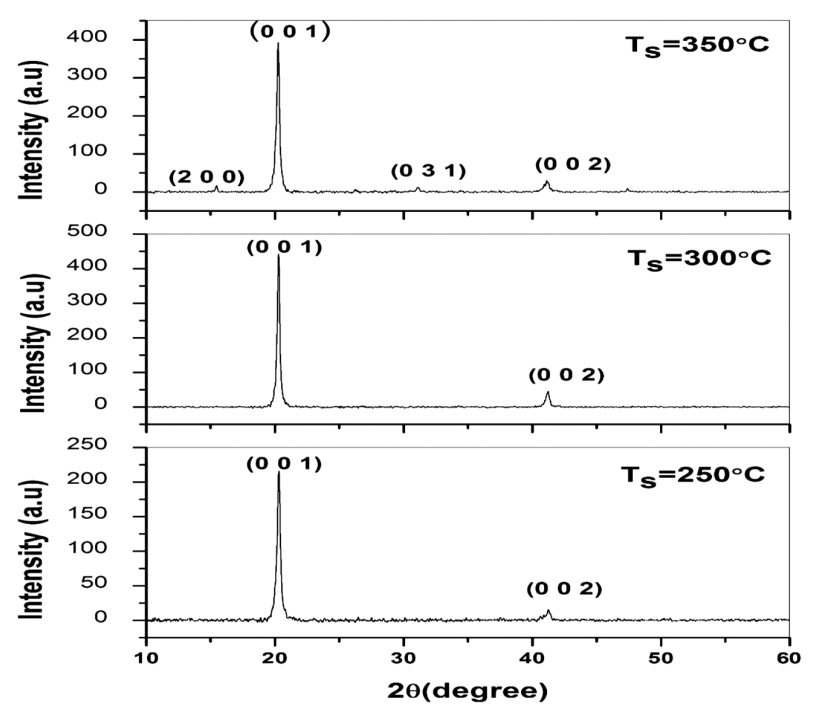

Figure 1: X-ray diffraction patterns of $\mathrm{V}_{2} \mathrm{O}_{5}$ films at different substrate temperatures

Slika 1: Posnetek rentgenske difrakcije tanke plasti $\mathrm{V}_{2} \mathrm{O}_{5}$ pri različnih temperaturah podlage heat sink to create a temperature gradient and produce the Seebeck voltage. The whole apparatus was kept in an enclosure to minimize the air-current disturbances. The temperature of the hot junction was raised slowly and the thermo e.m.f. was noted at regular intervals of $5{ }^{\circ} \mathrm{C}$. The thermo e.m.f. was measured with a Keithley nanovoltmeter (model no.181).

\section{RESULTS AND DISCUSSION}

\subsection{Structural properties}

The X-ray diffraction (XRD) patterns of $\mathrm{V}_{2} \mathrm{O}_{5}$ thin films at different substrate temperatures are shown in Figure 1. The peaks obtained in the XRD pattern match the peaks in JCPDS \# 89-2482, corresponding to the orthorhombic $\mathrm{V}_{2} \mathrm{O}_{5}$ phase with the lattice-parameter values of $a=1.154 \mathrm{~nm}, b=0.3571 \mathrm{~nm}$ and $c=0.4383 \mathrm{~nm}$. The $\mathrm{V}_{2} \mathrm{O}_{5}$ phase formation starts on the films deposited at the substrate temperature of $250{ }^{\circ} \mathrm{C}$ with the (001) reflection and this reflection was more dominant with the film deposited at $300{ }^{\circ} \mathrm{C}$. The XRD patterns suggest that the texture of a $\mathrm{V}_{2} \mathrm{O}_{5}$ thin film is oriented along the $c$-axis and, on a further increase in the substrate temperature, up to $350{ }^{\circ} \mathrm{C}$, other reflections - (200), (301) also appear. The orthorhombic $\mathrm{V}_{2} \mathrm{O}_{5}$ phase is in agreement with the earlier reports on the $\mathrm{V}_{2} \mathrm{O}_{5}$ thin films deposited with the spray pyrolysis and also with other methods. ${ }^{13,14}$ The crystallite size of the films was estimated with the Debye-Scherrer formula for the (001) reflection:

$$
d=\frac{0.94 \lambda}{\beta \cos \theta}
$$

where $d$ is the crystallite size, $\lambda$ is the $\mathrm{X}$-ray wavelength $(0.154 \mathrm{~nm}), \beta$ is the full-width half maximum and $\theta$ is the Bragg diffraction angle in degrees.

The variation in the crystallite size with the substrate temperature is summarized in Table 1. The results show that the crystallite size varies from $67 \mathrm{~nm}$ for the film deposited at $250{ }^{\circ} \mathrm{C}$ to $84 \mathrm{~nm}$ for the film deposited at $300{ }^{\circ} \mathrm{C}$ and it further changes to $74 \mathrm{~nm}$ for the film deposited at $350{ }^{\circ} \mathrm{C}$. It can also be observed that the crystallite size increases with the substrate temperature varying from $250{ }^{\circ} \mathrm{C}$ to $300{ }^{\circ} \mathrm{C}$. This could be associated with the coalescence process being favored in this temperature range, leading to an increase in the crystal-

Table 1: Variation in the crystallite size, optical band gap, activation energy and Seebeck coefficient with the substrate temperature

Tabela 1: Spreminjanje velikosti kristalitov, optične pasovne vrzeli in Seebeckovega koeficienta s temperaturo podlage

\begin{tabular}{|c|c|c|c|c|}
\hline $\begin{array}{c}\text { Substrate } \\
\text { temperature }\end{array}$ & $\begin{array}{c}\text { Crystallite } \\
\text { size } d / \mathrm{nm}\end{array}$ & $\begin{array}{c}\text { Optical } \\
\text { band gap } \\
E_{\mathrm{g}} / \mathrm{eV}\end{array}$ & $\begin{array}{c}\text { Activation } \\
\text { energy } \\
E_{\mathrm{a}} / \mathrm{eV}\end{array}$ & $\begin{array}{c}\text { Seebeck } \\
\text { coefficient } \\
S /(\mu \mathrm{V} / \mathrm{K})\end{array}$ \\
\hline $250^{\circ} \mathrm{C}$ & 67 & 2.34 & 0.15 & -70 \\
\hline $300^{\circ} \mathrm{C}$ & 84 & 2.29 & 0.13 & -66 \\
\hline $350^{\circ} \mathrm{C}$ & 74 & 2.21 & 0.12 & -65 \\
\hline
\end{tabular}




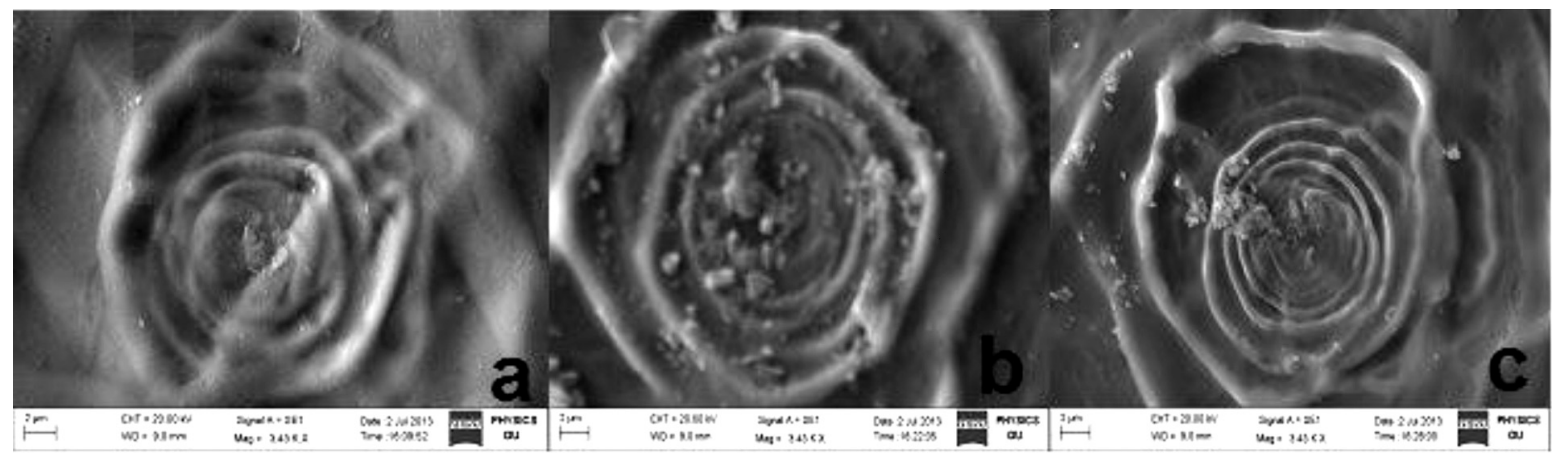

Figure 2: SEM images of $\mathrm{V}_{2} \mathrm{O}_{5}$ films at different substrate temperatures: a) $250{ }^{\circ} \mathrm{C}$, b) $300{ }^{\circ} \mathrm{C}$, c) $350{ }^{\circ} \mathrm{C}$ Slika 2: SEM-posnetki tanke plasti $\mathrm{V}_{2} \mathrm{O}_{5}$ pri različnih temperaturah podlage: a) $250{ }^{\circ} \mathrm{C}$, b) $300{ }^{\circ} \mathrm{C}$, c) $350{ }^{\circ} \mathrm{C}$

lite size. A further increase in the substrate temperature leads to a decrease in the crystallite size which may be due to the re-crystallization of the material.

The dislocation density $(\delta)$ is described as the length of dislocation lines per unit volume of the crystal. The dislocation density $(\delta)$ of the crystal gives information about the crystal structure. The dislocation density for the preferential orientation can be calculated using the formula below: ${ }^{15}$

$$
\delta=\frac{1}{d^{2}}
$$

where $d$ is the crystallite size. The dislocation density obtained from Equation (2) for various crystallite sizes is found to be $15 \cdot 10^{-3} \mathrm{~nm}^{-2}, 12 \cdot 10^{-3} \mathrm{~nm}^{-2}$ and 13 . $10^{-3} \mathrm{~nm}^{-2}$. It can be concluded from the above results that the smaller the dislocation density the better is the crystallization of the film.

Figure 2 presents the SEM images of the films deposited at different substrate temperatures. Similar results were observed for $\mathrm{MoO}_{3}$ thin films. ${ }^{16}$

It can be seen from the SEM images and analyses of the topographical profiles that the surfaces of the films

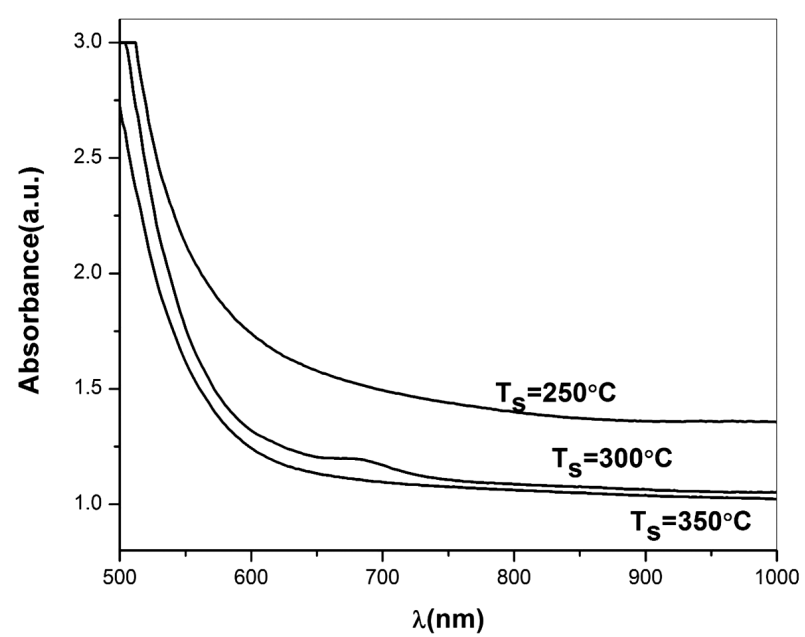

Figure 3: Absorbance versus wavelength at different substrate temperatures

Slika 3: Odvisnost absorbance od valovne dolžine pri različnih temperaturah podlage grown at a substrate temperature of $300{ }^{\circ} \mathrm{C}$ clearly grew like a sponge-type structure with macropores.

\subsection{Optical properties}

The impact of the substrate temperature on the optical energy-gap $\left(E_{\mathrm{g}}\right)$ values was investigated with the optical-absorbance measurements. The absorbance spectra of the films deposited at different substrate temperatures are presented in Figure 3. By increasing the substrate temperature, the absorbance of the films was increased. The optical absorption coefficient $\alpha$ was estimated with the following relation:

$$
\alpha=\frac{A}{t}
$$

where $t$ is the film thickness and $A$ is the absorbance.

According to the interband absorption theory, the optical band gap $\left(E_{\mathrm{g}}\right)$ of the films was calculated using the following relation:

$$
\alpha h v=B\left(h v-E_{\mathrm{g}}\right)^{\mathrm{m}}
$$

where $B$ is the probability parameter for the transition, $E_{\mathrm{g}}$ is the optical band gap of the material, $h v$ is the incident photon energy, and $m$ is the transition coefficient.

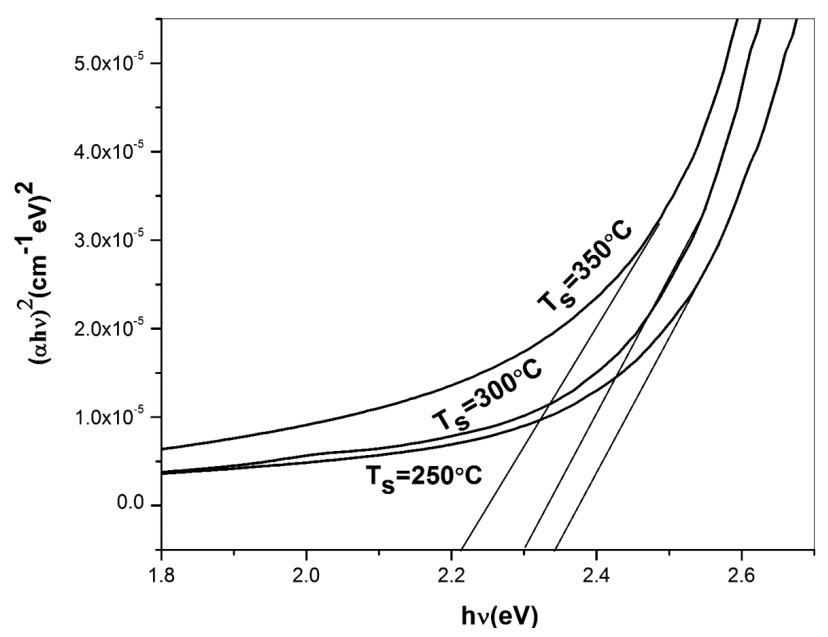

Figure 4: $(\alpha h v)^{2}$ versus $h v$ at different substrate temperatures Slika 4: Odvisnost $(\alpha h v)^{2}$ od $h v$ pri različnih temperaturah podlage 
The value of $m$ was taken as $1 / 2$ for direct transitions, $3 / 2$ for direct forbidden transitions, 2 for indirect transitions and 3 for indirect forbidden transitions. ${ }^{17}$

The plotting of $(\alpha h v)^{1 / m}$ versus the photon energy $(h v)$ and extrapolating it to $(\alpha h v)^{1 / m}=0$ gives the value of $E_{\mathrm{g}}$. Figure 4 shows the plots of $(\alpha h v)^{2}$ versus $h v$ for the $\mathrm{V}_{2} \mathrm{O}_{5}$ films deposited at different substrate temperatures. The results obey the above equation with $m=1 / 2$ indicating a direct transition. The calculated values of the optical band gap $E_{\mathrm{g}}$ were found to be $(2.34,2.29$ and 2.21$) \mathrm{eV}$ for the films deposited at $(250,300$ and 350$){ }^{\circ} \mathrm{C}$, respectively. These values for the $\mathrm{V}_{2} \mathrm{O}_{5}$ thin films investigated in the present study are consistent with the values reported $\mathrm{in}^{14}$. The decrease in the optical band gap is attributed to the microstructural changes caused by a high substrate temperature. At high temperatures the interatomic distance decreases, leading to a decrease in the localized states in the conduction and valance bands.

\subsection{Thermoelectric properties}

Figure 5 presents the room-temperature resistances of the films deposited at different substrate temperatures $\left(T_{\mathrm{s}}\right)$. It was found that the room-temperature surface resistance decreased from $180 \mathrm{k} \Omega$ to $50 \mathrm{k} \Omega$ as the substrate temperature increased from $250{ }^{\circ} \mathrm{C}$ to $350{ }^{\circ} \mathrm{C}$. We maintain that the resistances are related to the microstructures of the films, which strongly depend on the substrate temperature. The film growth is directly related to the diffusion of atoms into the substrates: ${ }^{18}$

$$
D=D_{0} \exp \left(-\frac{E_{\mathrm{d}}}{k T}\right)
$$

Here $D$ is the surface-atomic-diffusion coefficient, $E_{\mathrm{d}}$ is the activation energy (atom), $k$ is the Boltzmann constant and $T$ is the absolute temperature. In the film growth mechanism, it is evident that the resistance of the

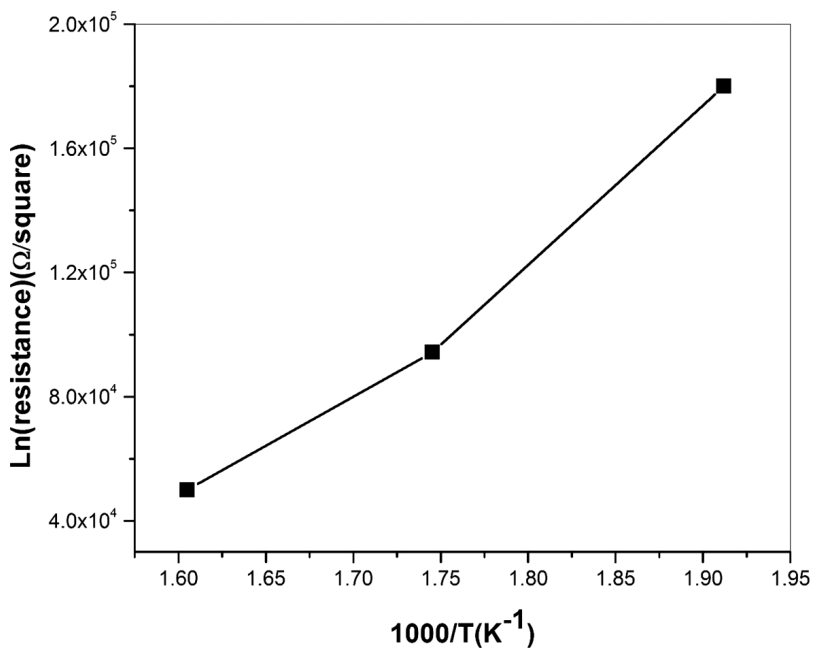

Figure 5: Resistance of $\mathrm{V}_{2} \mathrm{O}_{5}$ film versus the substrate temperature Slika 5: Odvisnost upornosti tanke plasti $\mathrm{V}_{2} \mathrm{O}_{5}$ od temperature podlage films is dependent on the substrate temperature which can be expressed with Equation (5) supported with Figure 5. At lower temperatures, the atoms may not have the sufficient energy for the atomic-jump process to overcome the potential energy of the nucleation sites of the substrate. At higher substrate temperatures, the mobility of atoms on the substrate surface is generally higher. As a result, the diffusion distance of atoms on the surface increases and the collision process initiates the nucleation for more atoms joined together, resulting in a decrease in the room-temperature resistance. To further investigate the electrical properties of the films, we measured the resistance and the temperature coefficient of resistance $(T C R)$ of the films. The variation in the resistance with different substrate temperatures is plotted in Figure 6. These plots are in good agreement with the thermal-activation mechanism evaluated with the following relation: ${ }^{19}$

$$
R=R_{0} \exp \left(\frac{E_{\mathrm{a}}}{k T}\right)
$$

where $R$ is the resistance, $R_{0}$ is the constant, $E_{\mathrm{a}}$ is the activation energy, $k$ is the Boltzmann constant and $T$ is the absolute temperature. The values of $E_{\mathrm{a}}$ derived according to the plots shown in Figure 7, using Equation (6) are $(0.15,0.13$ and 0.12$) \mathrm{eV}$. These results indicate that electrons need less activation energy to jump from a vanadium site to another one with an increased temperature as the substrate temperature increased. They also explain that in the case of a film grown at a higher substrate temperature, atoms are closely packed, there are fewer defects and, hence, the hopping energy related to the thermally assisted tunneling process decreases. ${ }^{18}$ The temperature coefficient of resistance $(T C R)$ can be calculated as: ${ }^{20}$

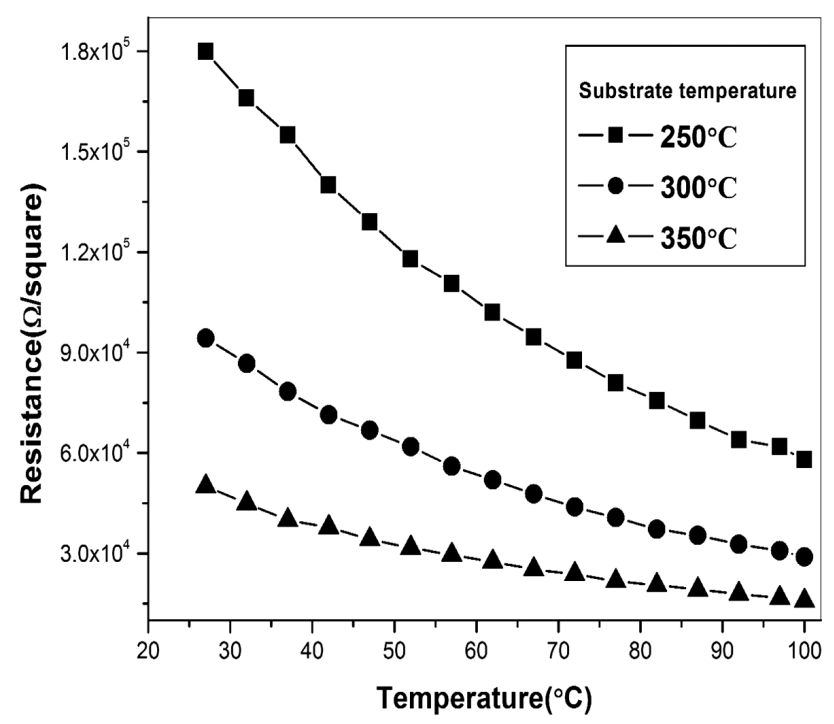

Figure 6: Resistance of $\mathrm{V}_{2} \mathrm{O}_{5}$ thin films as a function of the heating temperature

Slika 6: Upornost tanke plasti $\mathrm{V}_{2} \mathrm{O}_{5}$ kot funkcija temperature ogrevanja 


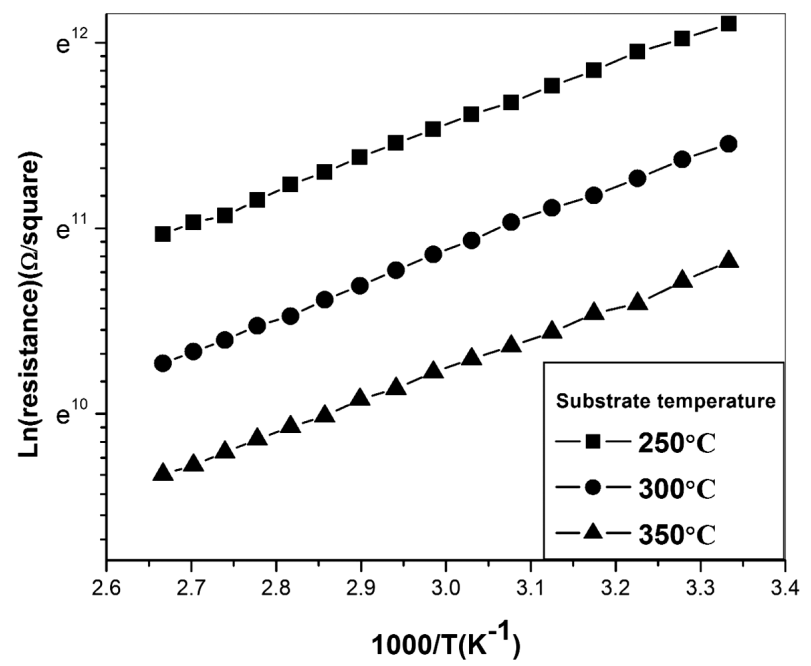

Figure 7: $L_{\mathrm{n}}$ (resistance) versus 1000/T

Slika 7: Odvisnost $L_{\mathrm{n}}$ (upornost) od 1000/T

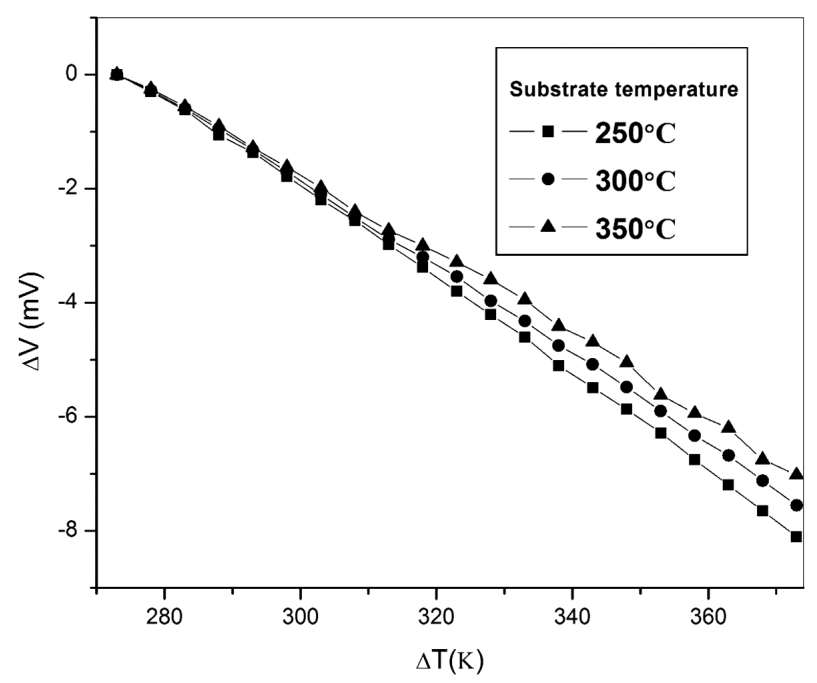

Figure 8: $\Delta V$ versus $\Delta T$ for different substrate temperatures Slika 8: Odvisnost $\Delta V$ od $\Delta T$ pri različnih temperaturah podlage

$$
T C R=\frac{\ln R}{\mathrm{~d} T}
$$

where $R$ is the resistance and $T$ is the absolute temperature.

The $T C R$ values are $(1.53,1.59$ and 1.50$) \cdot 10^{-2} \mathrm{~K}^{-1}$ for the substrate temperatures of $(250,300$ and 350$){ }^{\circ} \mathrm{C}$, respectively. The increase in the $T C R$ value up to 1.59 . $10^{-2} \mathrm{~K}^{-1}$ at the substrate temperature of $300{ }^{\circ} \mathrm{C}$ may be due to a more intense crystallization of the film at this temperature.

The Seebeck coefficient was determined by measuring the thermo e.m.f $(\Delta V)$ as a function of the temperature difference $(\Delta T)$. Typical data from the Seebeck measurements are shown in Figure 8, the thermo e.m.f. $(\Delta V)$ shows a linear dependence of $\Delta T$. The negative value of the thermo e.m.f. was consistent with the n-type semiconductor behavior. The Seebeck coefficient $(S)$ could be found from the slope of the graphs (Figure 8): ${ }^{21}$

$$
S=\frac{\Delta V}{\Delta T}
$$

The Seebeck-coefficient value increases as the substrate temperature $T_{\mathrm{s}}$ is increased to the maximum value of $65 \mu \mathrm{V} / \mathrm{K}$ at $350{ }^{\circ} \mathrm{C}$. The enhancement of the Seebeck-coefficient value due to the increase in the substrate temperature leads to a decrease in the activation energy, which can be attributed to the improvement in the crystallinity compared to the low-substrate-temperature films. The thermoelectric properties of the $\mathrm{V}_{2} \mathrm{O}_{5}$ thin films produced are relatively suitable for the IR sensor applications.

\section{CONCLUSIONS}

$\mathrm{V}_{2} \mathrm{O}_{5}$ thin films were prepared, with spray pyrolysis, on glass substrates at different substrate temperatures. XRD patterns of the $\mathrm{V}_{2} \mathrm{O}_{5}$ thin films showed a crystalline orthorhombic structure with the preferential orientation of (001). The films deposited at a temperature of $300{ }^{\circ} \mathrm{C}$ are well textured and $c$-axis oriented with good crystalline properties. The optical band gaps of the films prepared at different temperatures are found to be $(2.27$, 2.25 and 2.16) eV. The electrical resistance decreased with an increase in the substrate temperature. The electrical resistance, TCR and the Seebeck coefficient of the $\mathrm{V}_{2} \mathrm{O}_{5}$ films were also strongly influenced by the substrate temperature.

\section{Acknowledgment}

One of the authors, Y. V. K., thanks the UGC, New Delhi, for providing the financial assistance in the form of RFSMS. M. V. R. R. thanks UGC-MRP F.41-907/ 2012(SR), New Delhi, and DST-PURSE, Osmania University, Hyderabad, for providing the financial assistance in the form of a project.

\section{REFERENCES}

${ }^{1}$ K. Nagase, Y. Shimizu, N. Miura, N. Yamazoe, Electrochromic properties of vanadium pentoxide thin films prepared by new wet process, Appl. Phys. Lett., 60 (1992) 7, 802, doi:10.1063/1.106523

${ }^{2}$ R. T. Rajendra Kumar, B. Karunagaran, D. Mangalaraj, S. K. Narayandass, P. Manoravi, M. Joseph et al., Room temperature deposited vanadium oxide thin films for uncooled infrared detectors, Mater. Res. Bull., 38 (2003) 7, 1235-1240, doi:10.1016/S0025-5408 (03)00118-1

${ }^{3}$ D. Manno, A. Serra, M. DiGiulio, G. Micocci, A. Taurino, A. Tepore et al., Structural and electrical properties of sputtered vanadium oxide thin films for applications as gas sensing material, J. Appl. Phys., 81 (1997) 6, 2709-2714, doi:10.1063/1.363973

${ }^{4}$ M. Ponzi, C. Duschatzky, A. Carrascull, E. Ponzi, Obtaining benzaldehyde via promoted V2O5 catalysts, Appl. Catal. A, 169 (1998) 2, 373-379, doi:10.1016/S0926-860X(98)00026-X

${ }^{5}$ M. F. Al-Kuhaili, E. E. Khawaja, D. C. Ingram, S. M. A. Durrani, A study of thin films of $\mathrm{V}_{2} \mathrm{O}_{5}$ containing molybdenum from an evaporation boat, Thin Solid Films, 460 (2004) 1-2, 30-35, doi:10.1016/ j.tsf.2004.01.076 
${ }^{6}$ C. V. Ramana, B. S. Naidu, O. M. Hussain, R. Pinto, Low-temperature growth of vanadium pentoxide thin films produced by pulsed laser ablation, J. Phys. D: Appl. Phys., 34 (2001) 7, L35, doi:10.1088/0022-3727/34/7/101

${ }^{7}$ C. W. Zou, X. D. Yan, J. Han, R. Q. Chen, W. Gao, Microstructures and optical properties of $\beta-\mathrm{V}_{2} \mathrm{O}_{5}$ nanorods prepared by magnetron sputtering, J. Phys. D: Appl. Phys., 42 (2009) 14, 145402, doi:10.1088/0022-3727/42/14/145402

${ }^{8}$ Y. V. Kumar, M. V. R. Reddy, K. N. Reddy, Preparation and optical characterization of $\mathrm{V}_{2} \mathrm{O}_{5}$ thin films, International Conference on Nanoscience, Engineering and Technology (ICONSET), Chennai, India, 2011, 244-246, doi:10.1109/ICONSET.2011.6167931

${ }^{9}$ M. A. Kaid, Characterization of Electrochromic Vanadium Pentoxide Thin Films Prepared By Spray Pyrolysis, Egypt. J. Solids, 29 (2006) 2, 273-291

${ }^{10}$ P. S. Patil, Versatility of chemical spray pyrolysis technique, Materials Chemistry and Physics, 59 (1999) 3, 185-198, doi:10.1016/ S0254-0584(99)00049-8

${ }^{11}$ P. S. Patil, Preparation and characterization of spray pyrolyzed nickel oxide (NiO) thin films, Appl. Surf. Sci., 199 (2002) 1-4, 211-221, doi:10.1016/S0169-4332(02)00839-5

${ }^{12}$ M. Mousavi, A. Kompany, N. Shahtahmasebi, M. M. Bagheri-Mohagheghi, Study of structural, electrical and optical properties of vanadium oxide condensed films deposited by spray pyrolysis technique, Adv. Manuf., 1 (2013) 4, 320-328, doi:10.1007/s40436013-0045-y

${ }^{13}$ A. Kumar, P. Singh, N. Kulkarni, D. Kaur, Structural and optical studies of nanocrystalline V2O5 thin films, Thin Solid Films, 516 (2008) 6, 912-918, doi:10.1016/j.tsf.2007.04.165
${ }^{14}$ R. Irani, S. M. Rozati, S. Beke, Structural and optical properties of nanostructural $\mathrm{V}_{2} \mathrm{O}_{5}$ thin films deposited by spray pyrolysis technique: Effect of the substrate temperature, Materials Chemistry and Physics, 139 (2013) 2-3, 489-493, doi:10.1016/j.matchemphys. 2013.01.046

${ }^{15}$ S. Aydogu, O. Sendil, M. B. Coban, The Optical and Structural Properties of ZnO Thin Films Deposited by the Spray Pyrolysis Technique, Chinese Journal of Physics, 50 (2012) 1, 89-100

${ }^{16}$ H. M. Martínez, J. Torres, L. D. López-Carreño, M. E. RodríguezGarcía, The Effect of Substrate Temperature on the Optical Properties of MoO3 Nano-crystals Prepared Using Spray Pyrolysis, J. Supercond. Nov. Magn., 26 (2013) 7, 2485-2488, doi:10.1007/ s10948-012-1692-0

${ }^{17}$ G. A. Khan, C. A. Hogarth, Optical absorption spectra of evaporated $\mathrm{V}_{2} \mathrm{O}_{5}$ and co-evaporated V2O5/B2O3 thin films, Journal of Materials Science, 26 (1991) 2, 412-416, doi:10.1007/BF00576535

${ }^{18}$ Z. Luo, Z. Wu, X. Xu, M. Du, T. Wang, Y. Jiang, Impact of substrate temperature on the microstructure, electrical and optical properties of sputtered nanoparticle $\mathrm{V}_{2} \mathrm{O}_{5}$ thin films, Vacuum, 85 (2010) 2, 145-150, doi:1016/j.vacuum.2010.05.001

${ }^{19}$ R. M. Öksüzoğlu, P. Bilgiç, M. Yıldırım, O. Deniz, Influence of post-annealing on electrical, structural and optical properties of vanadium oxide thin films, Optics and Laser Technology, 48 (2013), 102-109, doi:10.1016/j.optlastec.2012.10.001

${ }^{20} \mathrm{H}$. Wang, X. Yi, S. Chen, Low temperature fabrication of vanadium oxide films for uncooled bolometric detectors, Infrared Physics \& Technology, 47 (2006) 3, 273-277, doi:10.1016/j.infrared.2005.04. 001

${ }^{21}$ S. Iwanaga, M. Marciniak, R. B. Darling, F. S. Ohuchi, Thermopower and electrical conductivity of sodium-doped V2O5 thin films, J. Appl. Phys., 101 (2007), 123709, doi:10.1063/1.2739311 